\title{
Konsep Kesehatan Reproduksi Perempuan dalam al-Qur'an
}

\section{Ratna Dewi}

IAIN Syaikh Abdurrahman Siddik Bangka Belitung, Indonesia ratnadewimalik@gmail.com

\begin{abstract}
The purpose of this study is to find out the verses of the Qur'an related to women's reproductive health, as well as the contextual interpretation of the commentators, so that it can be seen that the Qur'an is concerned with the reproductive health of women. The concept of reproductive health of women according to the Koran consists of six concepts, namely: Menstruation (Menstruation), sex and sexuality, pregnancy, childbirth, breastfeeding, and child care. All of these concepts are taken from the explanation of the Qur'an and so in the contextual interpretation of the commentators. The results of this study conclude that the commentators have a broad understanding relating to the science of reproductive health of women. Like menstruation, about menstrual blood described in the Surah Al-Baqarah verse: 222. Then the concept of the prohibition of adultery in Islam contained in Surah al-Isro 'verse: 32. Pregnancy, verses of the Qur'an that explain about pregnancy very much, among them, Al-Qur'an Surat Al-Mukminun verses 12-14. Childbirth, Al-Qur'an explains the verse about childbirth contained in the Surah Al-Ahqaf verse 15. Breastfeeding, Breastfeeding is also a function of reproduction. Verses that explain about breastfeeding include Surah Al-Baqarat verse 233. And caring for children, as Allah SWT says in the Qur'an is related to the care of children Lukman verse verse: 13.
\end{abstract}

Keywords; Health, Women's Reproduction, Al-Qur'an

\begin{abstract}
Abstrak
Tujuan penelitian ini adalah untuk mengetahui ayat-ayat al-Qur'ān yang berhubungan dengan kesehatan reproduksi perempuan, serta penjelasan penafsiran yang kontekstual dari para mufassir, sehingga dapat diketahui bahwa al-Qur'ān memang memperhatikan terhadap kesehatahan reproduksi perempuan. Konsep kesehatan reproduksi perempuan menurut alQur'ān terdiri dari enam konsep, yaitu: Menstruasi (Haid), Seks dan Seksualitas, kehamilan, persalinan, menyusui, dan perawatan anak. Semua konsep tersebut di ambil dari penjelaan alQur'ān dan sehingga dalam penafsiran yang kontekstual dari para mufassir. Hasil penelitian ini menyimpulkan bahwa para mufassir mempunyai pemahaman yang luas yang berkaitan dengan ilmu kesehatan reproduksi terhadap perempuan. Seperti menstruasi, tentang darah haid yang dijelaskan dalam Surat Al-Baqarah ayat: 222. Kemudian konsep larangan perzinaan dalam Islam yang terdapat dalam surat al-Isro' ayat: 32. Kehamilan, ayat Al-Qur'an yang menjelaskan tentang kehamilan sangat banyak, Diantaranya, Al-Qur'an Surat Al-Mukminun ayat 12-14. Persalinan, Al-Qur'an menjelaskan ayat tentang persalinan terdapat dalam Surat Al-Ahqafayat 15. Menyusui, Menyusui juga merupakan salah satu fungsi reproduksi. Ayat yang menjelaskan tentang menyusui antara lain Surat Al-Baqarat ayat 233. Dan Merawat anak, sebagaimana Allah SWT berfirman dalam al- Qur'an terkait dengan pemeliharaan anak Surat Lukman ayat: 13.
\end{abstract}

Kata Kunci; Kesehatan, Reproduksi Perempuan, Al-Qur'an.

Accepted: 18-11-2019; published: 30-12-2019

Citation: Ratna Dewi, 'Konsep Kesehatan Reproduksi Perempuan dalam al-Qur'an', Mawa'izh: Jurnal Dakwah dan Pengembangan Sosial Kemanusiaan, vol. 10, no. 2 (2019), pp. 248-272. 


\section{A. Pendahuluan}

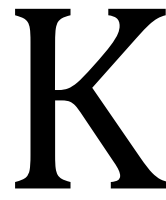

esehatan berasal dari kata sehat yaitu suatu keadaan (hal) dimana seluruh badan serta bagian-bagiannya dalam kondisi baik. ${ }^{1}$ Menurut UU Kesehatan No. yang memungkinkan setiap orang hidup produktif secara sosial dan ekonomi. Sedangkan menurut WHO (World Health Organization), sehat adalah memperbaiki kondisi manusia, baik jasmani, rohani ataupun akal, sosial dan bukan semata-mata memberantas penyakit. ${ }^{2}$ Reproduksi adalah suatu proses biologis suatu individu untuk menghasilkan individu baru. Kesehatan reproduksi sebagaimana yang didefinisikan oleh International Conference On Population and Development (ICPD) adalah kesehatan secara fisik, mental dan kesejahteraan sosial secara utuh pada semua hal yang berhubungan dengan sistem dan fungsi, serta proses reproduksi dan bukan hanya kondisi yang bebas dari penyakit atau kecacatan. ${ }^{3}$ Perempuan adalah orang (manusia) yang mempunyai vagina ${ }^{4}$, dapat menstruasi, hamil, melahirkan anak, dan menyusui. Moenawar Chalil dalam bukunya "Nilai Wanita", sebagaimana dikutip Arsyad Sobby Kesuma menjelaskan bahwa Perempuan disebut wanita, putri, istri, dan ibu yang merupakan sejenis makhluk dari bangsa manusia yang halus kulitnya, lemah sendi tulangnya dan agak berlainan bentuk serta susunan tubuhnya dibanding susunan tubuh laki-laki. ${ }^{5}$

Al-Qur'an adalah Kalamullah yang bernilai mukjizat, yang diturunkan kepada Nabi Muhammad SAW, dengan perantaraan malaikat Jibril yang tertulis pada mashahif, diriwayatkan kepada kita dengan mutawatir, dan bagi yang membacanya terhitung ibadah diawali dengan surat Al-Fatihah, dan ditutup dengan surat An-Nas. ${ }^{6} \mathrm{Al}-\mathrm{Qur}$ 'an adalah kitab suci umat Islam yang memerintahkan manusia untuk senantiasa hormat dan

1 Departemen Pendidikan Nasional, Kamus besar Bahasa Indonesia Pusat Bahasa Edisi Keempat (Jakarta: Gramedia, 2008), p. 1241.

${ }^{2}$ Ahmad Syauqi Al Fanjari, Nilai Kesehatan Dalam Syariat Islam, Terjemahan,Diterjemahkan Oleh Ahsin Wijaya Totok Jumantoro (Jakarta: Bumi Aksara, 1996), p. 4.

${ }^{3}$ Eny Kusmiran, Kesehatan Reproduksi Remaja dan Wanita (Jakarta: Salemba Medika, 2012) p. 94.

${ }^{4}$ Vagina merupakan organ kopulasi (persetubuhan) perempuan dan berguna untuk mengeluarkan ekskresi uterus. Selain itu vagina juga merupakan bagian saluran yang dilalui bayi pada saat melahirkan. Lihat Asep Sufyan Ramadhy, Biologi Reproduksi (Bandung: Refika Aditama, 2011), p. 48.

${ }^{5}$ Arsyad Sobby Kesuma, Diskursus Tafsir Hak-hak Politik Perempuan Dalam Al-Qur'an, Studi Tafsir Al-Misbah (IAIN Raden Intan Lampung: LP2M, 2016), p. 23.

${ }^{6}$ Syekh Muhammad Ali As-Shabuni, Ikhtisar Ulumul Qur'an Praktis (Jakarta: Pustaka Amani, 2001), p. 3. 
berbuat baik kepada perempuan (Ibu). Secara penuh al-Qur'an menegaskan kepada segenap manusia diberikan beban amat berat, beban reproduksi yang dipikul oleh kaum perempuan, serta kaum ibu. ${ }^{7}$

Kesehatan adalah sesuatu yang sangat vital sekali bagi kehidupan manusia, disamping kebutuhan sandang, pangan dan papan, karena kesehatan merupakan sarana dalam mencapai kehidupan yang bahagia. Kebutuhan hidup yang tersedia tidak akan berguna dan menjadi hambar apabila tidak diiringi dengan kesehatan badan. Dalam hal ini Rasulullah s.a.w. bersabda, sebagaimana hadis yang diriwayatkan oleh Nasai dari 'Amr bin Maimun dalam kitab As-Sunan al-Kubra berkata:"Perhatikanlah lima perkara ini sebelum datangnya lima perkara: hidupmu sebelum datang kematianmu, kesehatanmu sebelum datang sakitmu, kesempatanmu sebelum datang kesibukanmu, masa mudamu sebelum datang masa tuamu, kekayaanmu sebelum datang kefakiranmu. ${ }^{8}$

"Disamping itu setiap muslim yang sakit di perintahkan pula untuk berobat kepada ahlinya dan perbuatan tersebut juga bernilai ibadah sebagaimana yang pernah disabdakan oleh Nabi s.a.w.: "Allah tidak menurunkan sebuah penyakit melainkan menurunkan pula obatnya." (Riwayatal-Bukhariy dan Muslim dari Abu Hurairah). ${ }^{9}$

Islam juga mengajarkan prinsip-prinsip kesehatan, kebersihan dan kesucian lahir dan batin. Antara kesehatan jasmani dengan kesehatan rohani merupakan kesatuan sistem yang terpadu, sebab kesehatan jasmani dan rohani menjadi syarat bagi tercapainya suatu kehidupan yang sejahtera di dunia dan kebahagiaan di akhirat. Islam sebagai pedoman hidup tentunya memiliki kaitan erat dengan kesehatan reproduksi mengingat Islam memiliki aturan-aturan dalam kehidupan manusia yang bertujuan untuk mencapai kondisi yang sesuai dengan persyaratan kesehatan reproduksi.

Kesehatan perempuan adalah konsep yang merujuk kepada kondisi jasmani sebagai konsekuensi dari fungsi biologis seorang ibu, sehingga berkaitan dengan bekerjanya alat-alat reproduksi perempuan. ${ }^{10}$ Agar alat-alat reproduksi perempuan

\footnotetext{
${ }^{7}$ Lihat Q.S Lukman (31): 14.

8 Al-Baihaqi, Dalam Kitab شعب الايمان للبيهقس, Bab فصل فيما يقول العاطس فى جواب, Juz 8, Nomor Hadits 9882 (Maktabah Syamilah), p. 203.

${ }^{9}$ Laznah Pentashihan Mushaf Al-Qur'an, Fenomena Kejiwaan Manusia Dalam Perspektif Al-Qur'an dan Sains (Jakarta: Kementrian Agama RI, 2016), p. 115.

${ }^{10}$ Prihatini Ambaretnani, dkk, Upaya Meningkatkan dan Melindungi Kesehatan Reproduksi TKWI (Yogyakarta: Galang Press, 1996), p. 8.
} 
dapat bekerja dengan baik dan terlindungi. Seorang perempuan harus diberikan suatu pengarahan bagaimana menjaga kesehatan reproduksi, diantaranya dengan mempersiapkan dirinya baik secara jasmani maupun rohani. Misalnya dengan menjaga fisik dan mental, menghindari sedini mungkin sebagai penyakit dan gangguan yang akan menghambatnya dalam melaksanakan fungsi reproduksi.

Kesehatan reproduksi itu sendiri berarti keadaan kesejahteraan fisik, mental dan sosial yang utuh, bukan karena tidak adanya penyakit atau kelemahan dalam segala hal yang berhubunga dengan sistem reproduksi. Fungsi-sungsi reproduksi berarti bahwa perempuan dapat mempunyai kehidupan seks yang memuaskan dan aman, serta memiliki kemampuan untuk berreproduksi dan menentukan pilihan, apakah mereka ingim melakukannya dan seberapa banyak. ${ }^{11}$ Konsep ini merupakan konsep modern yang popular digunakan oleh berbagai praktisi, misalnya yang berkecimpung dalam bidang medis, pemerhati masalah perempuan bahkan smapai pendidikan.

Jika dilihat dari sudut fiqih, khususnya dari fiqih perempuan (fiqh-al-nisa) yang dalam pengertiannya secara makro bukan hanya meliputi seluruh aspek kehidupan baik itu ibadah maupun muamalah, melainkan lebih ditunjukan pada persoalan-persoalan khusus, yaitu persoalan mengenai reproduksi perempuan dalam istilah kontemporer sering disebut huquq al-muamahat. ${ }^{12}$ Meskipun khas perempuan dalam fiqh ini mempunyai kaitan dengan laki-laki. Disamping itu juga persoalan-persoalan repreduksi ini menjadi kajian ulama fiqih juga sehingga memberikan pandangan baik dalam tataran konsep maupun praktiknya. Maka dengan ini penulisan ingin meneliti tentang reproduksi kesehatan perempuan dalam al-qur'an ke dalam beberapa tahapan atau proses.

\section{B. Pengetahuan Kesehatan Reproduksi Perempuan}

\section{Konsep Kesehatan Reproduksi}

Kesehatam reproduksi adalah kesehatan secara fisik, mental, dan kesejahteraan sosial secara utuh pada semua hal yang berhubungan dengan sistem dan fungsi, serta proses reproduksi dan bukan hanya kondisi yang bebas dari penyakit atau kecacatan. ${ }^{13}$

p. 9.

11 Prihatini Ambaretnani, dkk, Upaya Meningkatkan dan Melindungi Kesehatan Reproduksi TKWI,

12 Ibrohim Muhammad al-Jamal, Fiqhul Mar'atil, Terj (Jakarta: Pustaka Amani, 1994), p. 2.

${ }^{13}$ Eny Kusmiran, Kesehatan Reproduksi Remaja dan Wanita (Jakarta: Salemba Medika, 2012), p. 94. 
Pada tahun 1994 di Kairo Mesir diselenggarakan konferensi International Conference on Population and Development. Konferensi Internasional ini tentang populasi dan pembangunan yang diikuti 179 negara ini merupakan salah satu tonggak sejarah bagi hak perempuan. Salah satunya yang pertama kali menetapkan kesehatan seksual/reproduksi sebagai sebuah hak yang komprehensif. Dalam Konferensi inilah ditetapkan definisi mengenai "kesehatan seksual". Kemudian Pada tahun 1995 diselenggarakan pula konferensi wanita sedunia ke-4 di Beijing. Paradigma dalam pengelolaan masalah kependudukan dan pembangunan telah mengalami perubahan sehingga menggunakan pendekatan pengendalian populasi dan penurunan fertilitas kemudian berubah menjadi pendekatan kesehatan reproduksi dengan memperhatikan kesehatan reproduksi dan kesetaraan gender. Perubahan ini telah disepakati dalam dua konferensi tersebut. Dalam kesepakatan itu pula kesehatan reproduksi didefinisikan sebagai keadaan sejahtera fisik, mental dan sosial secara utuh (tidak semata-mata bebas dari penyakit atau kecacatan) dalam semua hal yang berkaitan dengan sistem reproduksi, serta fungsi dan prosesnya. ${ }^{14}$

\section{Ruang Lingkup Kesehatan Reproduksi}

Ruang lingkup kesehatan reproduksi mencakup keseluruhan kehidupan manusia sejak lahir sampai mati. Pelaksanaan kesehatan reproduksi menggunakan pendekatan siklus hidup (life cycle approach) agar diperoleh sasaran yang pasti dan komponen pelayanan yang jelas serta dilaksanankan secara terpadu dan berkualitas dengan memperhatikan hak reproduksi perorangan dengan bertumpu pada program pelayanan yang tersedia. Dalam pendekatan siklus hidup dikenal lima tahap, yaitu tahap konsepsi, bayi dan anak, remaja, usia subur dan usia lanjut. Secara luas, ruang lingkup kesehatan reproduksi meliputi hal-hal berikut:

- Kesehatan ibu dan bayi baru lahir;

- Keluarga Berencana (KB);

- Pencegahan dan penanggulangan infeksi saluran reprodusi (ISR) termasuk PMSHIV/AIDS;

- Pencegahan dan penanggulangan komplikasi aborsi;

\footnotetext{
14 Intan Kumala Sari, Iwan Andhyantoro, Kesehatan Reproduksi Untuk Mahasiswa Kebidanan dan Keperawatan (Jakarta: Salemba Medika, 2012), p. 1
} 
- Kesehatan reproduksi remaja;

- Pencegahan dan penanganan infertilitas;

- Kanker pada usia lanjut dan osteoporosis;

- Berbagai aspek kesehatan reproduksi lain, misalnya kanker serviks, mutilasi genital, fistula, dan lain-lain. ${ }^{15}$

Untuk kepentingan Indonesia saat ini, secara nasional telah disepakati ada empat komponen prioritas kesehatan reproduksi, yaitu: Kesehatan ibu dan bayi baru lahir, keluarga berencana, kesehatan reproduksi remaja, dan pencegahan serta penanggulangan penyakit menular seksual termasuk HIV/AIDS.

\section{Kesehatan Reproduksi Perempuan}

Alat Reproduksi perempuan adalah organ-organ yang berperan dalam serang kali proses yang bertujuan untuk berkembang biak atau memperbanyak keturunan. Agar manusia dapat memiliki anak, maka harus memiliki organ-organ reproduksi dengan fungsi dan dalam keadaan normal. Secara garis besar alat reproduksi perempuan terbagi kedalam dua kelompok, yaitu alat reproduksi (Genetalia) luar dan alat reproduksi (Genetalia) dalam.

\section{Genitalia Eksternal (Alat Reproduksi Luar)}

Istilah anatomi untuk alat reproduksi (Genetalia) perempuan bagian luar ialah Vulva. Vulva tersusun oleh beberapa struktur yang mengelilingi tempat masuk kelamin bagian dalam (vagina), dan masing-masing memiliki tugas tersendiri. ${ }^{16}$

\section{Mons pubis / mons veneris}

Mons veneris adalah bagian yang sedikit menonjol dan bagian yang menutupi tulang kemaluan (simfisis pubis). Bagian ini disusun oleh jaringan lemak dengan sedikit jaringan ikat. Mons Veneris juga sering dikenal dengan nama gunung venus, ketika dewasa bagian mons veneris akan ditutupi oleh rambut-rambut kemaluan dan membentuk pola seperti segitiga terbalik.

${ }^{15}$ Intan Kumala Sari, Iwan Andhyantoro, Kesehatan Reproduksi Untuk Mahasiswa Kebidanan dan Keperawatan, p. 2

16 Derek Llewellyn, Jones, Ginekologi \& Kesehatan Wanita, Terjemahan Kartono Muhammad (Jakarta: Gaya Favorit Press, 1991), p. 12. 


\section{Labia mayora (Bibir Besar Kemaluan)}

Seperti namanya, bagian ini berbentuk seperti bibir. Labia Mayora merupakan bagian lanjutan dari mons veneris yang berbentuk lonjok, menuju ke bawah dan bersatu membentuk perineum. Bagian Luar dari Labia Mayora disusun oleh jaringan lemak, kelenjar keringat, dan saat dewasa biasanya ditutupi oleh rambut-rambut kemaluan yang merupakan rambut dari mons veneris. Sedangkan selaput lemak yang tidak berambut, namun memiliki banyak ujung-ujung saraf sehingga sensitif saat fase-fase hubungan seks.

\section{Klitoris}

Merupakan organ erektil yang banyak mengandung pembuluh darah dan serabut saraf. Ukuran sebesar kacang polong, sangat sensitif terhadap rangsangan dan berperan besar dalam fungsi seksual saat mencapai orgasme. Ketika fase perangsangan, klitoris akan membesar dan menonjol. Klitoris analog dengan Penis pada Alat Reproduksi Pria.

\section{Vestibulum}

Bagian atas dibatasi oleh klitoris, bagian bawah fourchet, dan batas bagian lateral labia minora. Berasal dari sinus urogenital. Pada bagian ini terdapat enam lubang/orifisium yaitu orifisium uretra eksternum, introitus vaginae, duktus glandula bartolini kanan dan kiri dan duktus skene kanan.

\section{Introitus/orifisium vagina}

Merupakan bagian/lubang vagina. Beberapa milimeter lebih ke dalam tertutup lapisan tipis bermukosa disebut selaput dara/himen. Himen normal terdapat lubang kecil untuk aliran darah menstruasi, bentuk himen normal disebut lunaris, dapat berbentuk bulan sabit (semilunari, memiliki banyak lubang-lubang kecil/kribiformis, septum, atau fimbriae). Himen dapat sobek setelah koitus atau trauma lain, dan bentuk lubang menjadi tidak beraturan dengan robekan.

\section{Perineum}

Daerah antara tepi bawah vulva dengan tepi depan anus. Batas otot-otot diafragma pelvis. ${ }^{17}$

\section{Masalah Gangguan Kesehatan Reproduksi Perempuan}

\footnotetext{
17 Intan Kumala Sari, Iwan Andhyantoro, Kesehatan Reproduksi Untuk Mahasiswa Kebidanan dan
} Keperawatan, p. 3 


\section{Infertilitas}

Infertilitas atau ketidak suburan adalah ketidak mampuan pasangan usia subur (PUS) untuk memperoleh keturunan setelah melakukan hubungan seksual secara teratur dan benar tanpa usaha pencegahan lebih dari satu tahun. Angka satu tahun ditetapkan karena biasanya $85 \%$ pasangan dalam satu tahun sudah memiliki keturunan.

\section{Kehamilan Yang Tidak Diinginkan (Unwanted Pregnancy)}

Kehamilan yang tidak diinginkan (KTD) adalah suatu kehamilan yang terjadi dikarenakan suatu sebab sehingga keberadaannya tidak diinginkan oleh salah satu atau kedua calon orangtua bayi tersebut. ${ }^{18}$ KTD sering dikaitkan dengan kehamilan remaja. Karena sebagian besar kehamilan remaja merupakan kehamilan yang tidak diinginkan. Beberapa risiko yang timbul akibat kehamilan yang tidak diinginkan diantaranya meliputi risiko medis seperti aborsi tidak aman berkontribusi pada kematian dan kesakitan ibu, risiko psikologis seperti rasa bersalah dan depresi, serta risiko psikososial seperti dikucilkan dari masyarakat dan hilang kepercayaan diri.

\section{Aborsi}

Secara medis aborsi adalah berakhir atau gugurnya kehamilan sebelum kandungan mencapai usia 20 minggu, yaitu sebelum janin dapat hidup di luar kandungan secara mandiri. Aborsi dapat dibedakan menjadi dua jenis, yaitu: Abortus Spontaneous (yang tidak disengaja) yaitu terjadi apabila ibu mengalami trauma berat akibat penyakit menahun, kelainan saluran reproduksi, atau kondisi patologis lainnya, dan Abortus provocatus (buatan) yaitu pengguguran kandungan yang dilakukan secara sengaja. Abortus provocatus dibedakan lagi menjadi dua bagian, yaitu: Abortus provocatus therapeuticus (jika terdapat indikasi bahwa kehamilan dapat membahayakan atau mengancam nyawa ibu apabila kehamilan itu berlanjut) dan Abortus provocatus criminalis (pengguguran kandungan yang dilakukan secara sengaja tanpa mempunyai alasan kesehatan atau medis). ${ }^{19}$

\section{Gangguan dan Masalah Menstruasi dalam Sistem Reproduksi}

Menstruasi atau yang lebih dikenal dengan istilah haid merupakan peluruhan dinding rahim yang terdiri atas darah dan jaringan tubuh. Pada jarak waktu tertentu sejak

\footnotetext{
18 Eny Kusmiran, Kesehatan Reproduksi Remaja dan Wanita, p. 36.

${ }^{19}$ Eny Kusmiran, Kesehatan Reproduksi Remaja dan Wanita, p. 38
} 
menarche (haid pertama kali datang) pada mulanya tidak teratur, tetapi semakin lama semakin teratur gadis tersebut mengalami haid. Dalam waktu 4-6 tahun sejak menarche (kira-kira pada umur 17-19 tahun) pola menstruasinya sudah akan terbentuk. Pada umumnya menstruasi datang sebulan sekali hingga ia kira-kira berumur 45 tahun. ${ }^{20}$ Pada saat ini haidnya kembali tidak teratur lagi. Umumnya tak ada keluhan berarti berkaitan dengan kedatangannya kecuali sedikit mulas atau ketidakstabilan emosi. Tetapi ada pula perempuan yang memiliki keluhan lebih mendalam karena proses menstruasinya sudah dirasakan bermasalah baik siklus, jumlah darah, atau nyerinya. Gangguan menstruasi dan siklusnya dalam masa reproduksi dapat digolongkan berdasarkan kelainan dalam banyaknya darah dan lamanya pendarahan pada menstruasi (hipermenore atau menoragia dan hipomenore), kelainan siklus (polimenore, oligomenore, amenore), pendarahan di luar menstruasi (metroragia), gangguan lain yang ada hubungan dengan menstruasi (ketegangan pramenstruasi-premenstrual tension, mastodinia, rasa nyeri pada ovulasi-mittelschmerz, dan dismenore). ${ }^{21}$

\section{Penyakit Menular Seksual}

Penyakit Menular Seksual (PSM) merupakan penyakit yang menular melalui hubungan seksual (hubungan kelamin). Penyakit menular seksual merupakan salah satu infeksi saluran reproduksi (ISR) yang ditularkan melalui hubungan kelamin. ISR merupakan infeksi yang disebabkan oleh masuk dan berkembang biaknya kuman penyebab infeksi ke dalam saluran reproduksi. Kuman penyebab infeksi tersebut dapat berupa jamur, virus dan parasit.22

\section{E. Kesehatan Reproduksi Perempuan Dalam Islam}

Islam berbeda dengan agama lain yang datang sebelumnya. Islam datang sebagai agama dan untuk kepentingan duniawi serta ukhrawi secara simultan. Tidak sekedar terbatas jalur hubungan antara hamba dengan Tuhan saja (vertikal), akan tetapi Islam adalah satu-satunya agama yang menegakkan daulat dan pemerintahan (horizontal),

\footnotetext{
${ }^{20}$ Derek Llewellyn, Jones, Ginekologi \& Kesehatan Wanita, p. 32.

${ }^{21}$ Intan Kumala Sari, Iwan Andhyantoro, Kesehatan Reproduksi Untuk Mahasiswa Kebidanan dan Keperawatan, p. 65.

22 Kathy French, Kesehatan Seksual, Terjemahan, Terjemahan Bhetsy Angelina (Jakarta: Bumi Medika, 2015), p. 63.
} 
yakni pemerintahan Rasulullah saw di Madinah. Kemudian dari langit diturunkan wahyu secara menyeluruh untuk mengatur kedaulatan dengan segala aspek yang terkait dengannya, sebagai undang-undang yang abadi. Undang-undang ini benar-benar mengandung aturan-aturan tentang politik, hukum, militer, pertahanan, ekonomi, kemasyarakatan dan moral secara sempurna. Dengan demikian memungkinkan bagi kita untuk mengatakan bahwa Islam adalah satu-satunya agama yang datang laksana undangundang dasar, atau protokol-protokol yang mengatur kedokteran, pengobatan dan kesehatan masyarakat. Termasuk di dalamnya tentang kesehatan reproduksi perempuan. ${ }^{23}$

Diantara pokok-pokok kandungan syariat Islam tentang kesehatan reproduksi perempuan, yaitu:

- Personal Hygiene (Kesehatan perorangan), yang meliputi kebersihan badan, tangan, gigi, kuku dan rambut. Termasuk didalamnya menjaga kebersihan organ-organ reproduksi.

- Epidemiologi (Preventif penyakit menular) yaitu: melalui karantina, preventif kesehatan, tidak memasuki suatu daerah yang terjangkit wabah penyakit, tidak lari dari tempat itu, mencuci tangan sebelum menjenguk orang sakit dan sesudahnya, berobat ke dokter dan mengikuti semua petunjuk preventif dan terapinya. Menghindari kemungkinan-kemungkinan terjangkitnya penyakit menular berbahaya seperti HIV, AIDS, dan penyakit menular seksual karena tidak mengindahkan budaya hidup sehat dan tidak menjalankan aturan-aturan agama.

- Nutrition (kesehatan makanan). Masalah ini terbagi kepada tiga bagian, yaitu: Pertama, menu makanan yang berfaedah terhadap kesehatan jasmani. Seperti tumbuh-tumbuhan, binatang laut, madu, kurma dan semua yang bergizi. Kedua, tata makanan. Islam melarang berlebih-lebihan dalam hal makanan, makan bukan karena lapar hingga kekenyangan, memerintahkan berpuasa agar usus dan perut besarnya dapat beristirahat. Ketiga, mengharamkan segala sesuatu yang berbahaya bagi kesehatan. Seperti bangkai, darah dan daging babi. Kesehatan makanan ini penting terlebih untuk perempuan yang sedang hamil dan menyusui anaknya, karena di masa-

${ }^{23}$ Ahmad Syauqi Al Fanjari, Nilai Kesehatan Dalam Syariat Islam, p. 4. 
masa inilah seorang perempuan sangat membutuhkan makanan yang sehat dengan nutrisi dan gizi yang cukup untuk kesehatan dan keselamatan dirinya dan anaknya.

- Sex hygiene (Kesehatan seks). Yakni meliputi hal-hal yang berkaitan dengan seks, embrio dan perkembangannya, pendidikan seks, cara memilih istri bahkan program pendidikan tentang hubungan seks yang aman. Demikian juga tentang kebersihan seks, seperti mandi setelah bersetubuh, istinja' setelah kencing dan berak, tidak menggauli istri ketika haidh, diharamkan zina, homoseks atau onani.

- Mental and psychic hygiene (Kesehatan mental dan jasmani). Mengingat beban berat yang harus dipikul oleh seorang perempuan ketika ia mengandung dan melahirkan. Diantara bentuk kesusah payahan yang dialami seorang ibu ketika hamil yaitu berupa mengidam, kekacauan pikiran maupun beban yang berat dan lain sebagainya yang biasa dialami oleh orang-orang hamil. Dan ketika melahirkan juga mengalami susah payah berupa rasa sakit menjelang kelahiran anak maupun ketika kelahiran itu berlangsung. Di saat-saat seperti itulah seorang perempuan sangat membutuhkan perhatian dan kasih sayang diantaranya supaya mencegah sebab terjadinya stres. Untuk itu Islam mengajarkan percaya kepada Allah dan bersabar dalam menghadapi berbagai penyakit yang kritis, tidak putus asa, bunuh diri, kehilangan kepercayaan atau zalim. Islam juga melarang semua benda yang dapat menghilangkan kesadaran dan melemahkan intuisi, seperti khamar, tipsi dan lain-lain. ${ }^{24}$

- Body built (Bina raga). Islam mendorong untuk memiliki keterampilan dan olahraga yang bermanfaat. Dengan berolahraga seorang perempuan dapat menjaga kesehatan tubuhnya termasuk organ-organ reproduksinya.

- Maternal and child health (Kesehatan ibu dan anak). Islam sangat menaruh perhatiannya terhadap pemeliharaan kesehatan ibu secara umum, ibu yang sedang hamil atau yang sedang menyusui khususnya, tidak membebaninya dengan tugastugas yang berat sebagai mana laki-laki, tidak memberi tugas berperang di medan laga. Islam menganggap menyusui anak merupakan suatu perjuangan, sama halnya dengan jihad kaum pria, sedangkan mati ketika sedang menyusui anak sama dengan orang yang mati syahid di medan pertempuran. Demi kesehatan anak, dan untuk menjarangkan kelahiran, biasanya menyusui dilakukan sepanjang dua tahun penuh.

\footnotetext{
${ }^{24}$ Ahmad Syauqi Al Fanjari, Nilai Kesehatan Dalam Syariat Islam, p. 6
} 


\section{F. Ruang Lingkup Kesehatan Reproduksi Perempuan Dalam Islam \\ 1. Menstruasi (Haid)}

Menstruasi secara biologis merupakan siklus reproduksi yang menandai sehat dan berfungsinya organ-organ reproduksi perempuan. Dari sisi biologis, perempuan yang sudah mengalami haid merupakan indikasi bahwa perempuan tersebut telah mampu bereproduksi, yakni mengalami proses kehamilan dan melahirkan. Al-Qur'an menyinggung masalah haid, yang merupakan bagian awal dari proses bimbingan dan perhatian terhadapan kesehatan reproduksi perempuan.

Menstruasi menandakan kematangan seksual seorang perempuan dalam arti ia mempunyai ovum yang siap dibuahi, bisa hamil, dan melahirkan anak. Oleh para ulama fiqih siklus ini disebut dengan istilah haid. Al-Qur'an menjelaskan tentang apa itu darah haid, dan bagaimana tata pergaulan dengan perempuan yang sedang haid, dalam QS. AlBaqarah/2:222.

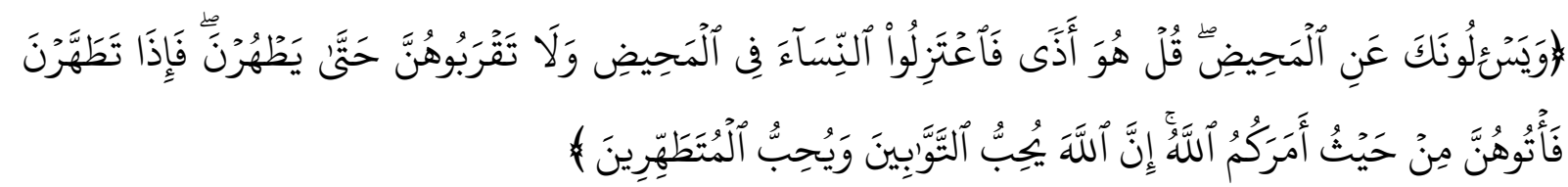

"Mereka bertanya kepadamu tentang haidh. Katakanlah: "Haidh itu adalah suatu kotoran". Oleh sebab itu hendaklah kamu menjauhkan diri dari wanita di waktu haidh; dan janganlah kamu mendekati mereka, sebelum mereka suci apabila mereka telah Suci. ${ }^{25}$

Ayat tersebut mengisyaratkan bahwa haid itu artinya kotoran. Kotoran berarti sisa, bekas. Al-adza dalam konteks haid adalah sel telur yang tidak dibuahi, kemudian mati, dan tidak berguna lagi. Pada waktunya akan keluar bersama darah, yang dikenal dengan haid. Darah haid adalah darah yang keluar dari farji perempuan dalam keadaan normal (sehat), bukan disebabkan melahirkan anak atau pecahnya selaput darah. Dan menurut ijma' para ulama' bahwa darah haid itu adalah najis. ${ }^{26}$ Syaikh Mushthafa AlAdawi dalam bukunya Jami' Al-Ahkam An-Nisa' sebagaimana dikutip syaikh Imad Zaki Al-Barudi menjelaskan bahwa para ulama' sepakat tentang keharaman berhubungan

${ }^{25}$ Ahmad Mustafa Al-Maragi, Tafsir Al-Maragi Jil. 2, Terjemahan Anshori, Hery, Bahrun (Semarang: Toha Putra, 1992), p. 267-68.

${ }^{26}$ Mahtuf Ahnan, Maria Ulfa, Risalah Fiqih Wanita (Surabaya: Terbit Terang, tth), p. 41. 
intim dengan wanita yang sedang haidh, di vaginanya. Ijma' ini diriwayatkan oleh sejumlah besar ulama, seperti Imam Ath-Thabari dan Al-Hazm. ${ }^{27}$

Haid dan wanita adalah dua hal yang tidak bisa dipisahkan. Setiap wanita dipastikan akan mengalaminya karena darah haid merupakan sifat alamiyah setiap wanita. Ketentuan ini sebagaimana digambarkan oleh Nabi Muhammad saw, bahwa haid adalah sesuatu yang sudah ditetapkan oleh Allah SWT. untuk kaum perempuan. Haid adalah pajak wajib yang diberikan Allah atas anak-anak wanita Banî Adam (Lammadhah, 1998), sebagaimana yang disabdakan

Rasulullah: "Ali bin Abdullah menuturkan hadîts kepada kami, dia berkata: Sufyân berkata: aku mendengar Abdurrahman bin Al-Qasim, dia berkata: aku mendengar AlQâsim bin Muhammad, dia berkata: aku mendengar Âisyah berkata: kami keluar untuk berhaji, lalu ketika kami berada di daerah Sarif, aku haid. Kemudian aku pergi ke Rasulullah dan aku menangis, lalu Rasulullah bersabda: apakah kamu haid? Dan aku menjawab: iya. Maka Rasulullah bersabda: Ini adalah sesuatu yang telah Allah tetapkan atas anak-anak wanita Adam".

\section{Seks dan Seksualitas}

Seks adalah perbedaan badani atau biologis perempuan dan laki-laki, yang sering disebut jenis kelamin. Sedangkan seksualitas menyangkut berbagai dimensi yang sangat luas, yaitu dimensi biologis, sosial, psikologis dan kultural. Secara normatif, Islam mengapresiasi seksualitas sebagai fitrah manusia, laki-laki maupun perempuan yang harus dikelola dengan sebaik-baiknya dan dengan cara yang yang sehat. Konsep seksualitas dalam Islam meliputi dua hal, yaitu perzinaan dan perkawinan.

\section{Konsep Perzinaan dalam Islam}

Zina adalah sebuah hubungan kelamin antara laki-laki dan perempuan tanpa memiliki ikatan hubungan perkawinan secara sah. Dilakukan secara sadar serta tanpa adanya unsur syubhat. Zina adalah perbuatan yang sangat tercela dan pelakunya mendapatkan sanksi yang sangat berat, baik hukum dera maupan rajam karena alasan yang dapat dipertanggung jawabkan secara moral dan akal.

27 Saikh Imad Zaki Al-Barudi, Tafsir Wanita, Terjemahan Samson Rahman (Jakarta: Pustaka AlKautsar, 2010), p. 51. 


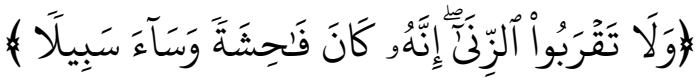

"Dan janganlah kamu mendekati zina; Sesungguhnya zina itu adalah suatu perbuatan yang keji. dan suatu jalan yang buruk." (QS Al-Isra (17): 32. ${ }^{28}$

Ayat tersebut menegaskan bahwa bukan hanya seks ilegal yang dilarang, tapi apapun yang menuntun seseorang menuju seks illegal tersebut. Berkhalwat laki-laki dan perempuan yang bukan muhrim, berpakaian yang merangsang, berbusana sangat minim, percabulan, dan pornografi. Aturan berpakaian bagi pria dan wanita dimaksudkan untuk memproteksi mereka dari godaan dan syahwat yang mungkin menghilangkan kontrol diri dan membuat mereka jatuh kedalam lembah dosa. ${ }^{29}$ Sebagaimana firman Allah dalam surat An-Nur ayat 30:

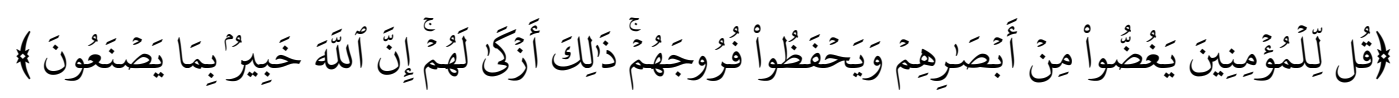

"Katakanlah kepada orang laki-laki yang beriman: "Hendaklah mereka menahan pandanganya, dan memelihara kemaluannya; yang demikian itu adalah lebih suci bagi mereka, Sesungguhnya Allah Maha mengetahui apa yang mereka perbuat".Dan katakanlah kepada wanita yang beriman: "Hendaklah mereka menahan pandangannya, dan kemaluannya...". 30

Al-Qur'an dan sunnah secara tegas menjelaskan hukum bagi pelaku zina baik yang belum menikah (ghoiru mushon) yakni didera seratus kali. Sementara bagi pelaku zina muhsan dikenakan sanksi rajam. Rajam secara bahasa berarti melempari batu, sedangkan menurut istilah, rajam adalah melempari pezina muhsan sampai menemui ajalnya. ${ }^{31}$ Sebagaimana firman Allah dalam surat An-Nur ayat 2 yang berbunyi:

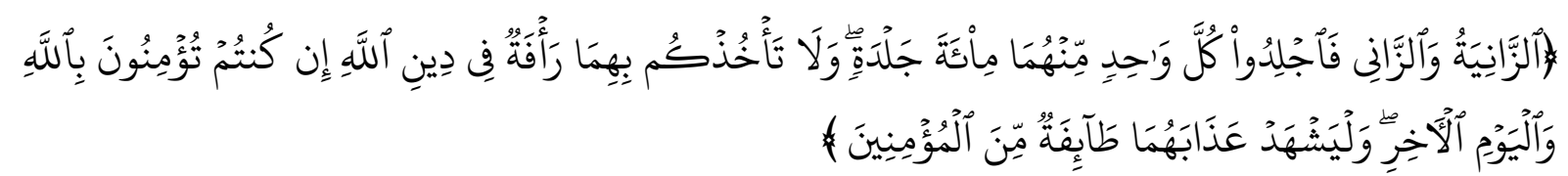

"Perempuan yang berzina dan laki-laki yang berzina, Maka deralah tiap-tiap seorang dari keduanya seratus dali dera, dan janganlah belas kasihan kepada keduanya mencegah kamu untuk (menjalankan) agama Allah, jika kamu beriman kepada Allah, dan

28 Ahmad Mustafa Al-Maragi, Tafsir Al-Maragi Jil. 15, Terjemahan Anshori, Hery, Bahrun (Semarang: Toha Putra, 1993), p. 52.

${ }_{29}$ Hassan Hathout, Bimbingan Seks Lengkap Bagi Kaum Muslim, Terjemahan, Terjemahan Yudi (Jakarta: Zahra, 2014), p. 14.

30 Ahmad Mustafa Al-Maragi, Tafsir Al-Maragi Jil. 18, Terjemahan Anshori, Hery, Bahrun (Semarang: Toha Putra, 1992), p. 169-70.

${ }^{31}$ Al-Imam Ibnu Qayyim al-Jauziyah, Jangan Dekati Zina, Terjemahan Tim Darul Haq (Jakarta: Darul Haq, 2012), p. 59 
hari akhirat, dan hendaklah (pelaksanaan) hukuman mereka disaksikan oleh sekumpulan orang-orang yang beriman." 32

Allah menggunakan kata لاتقربو di dalam Al-Qur'an sebanyak lima kali. ${ }^{33}$ Selain pada ayat tersebut di atas, Allah juga menggunakan kata itu pada surat An-Nisa': 43 untuk melarang seseorang melaksanakan salat dalam keadaan mabuk; surat Al-An'am: 151 tentang larangan mendekati perbuatan-perbuatan keji, dan surat Al-Isra' 34 dan surat alAn'am: 152 tentang larangan memakan harta anak yatim. Jika dicermati secara seksama, ada kemiripan larangan yang dikandung di dalam kelima ayat tersebut, antara lain: Pertama, perbuatan yang dilarang melalui ayat-ayat tersebut adalah puncak-puncak perbuatan. Artinya, ada perbuatan-perbuatan lain yang mendahului, mengantarkan atau mendukung perbuatan puncak itu sehingga terakumulasi menjadi satu perbuatan terlarang.

Perbuatan zina dan perbuatan memakan harta anak yatim sama-sama dilarang oleh Allah dengan menggunakan sighat yang sama yaitu لاتقربوا karena akibat yang timbul dari perbuatan itu hampir sama, yaitu menistakan atau menelantarkan orang lain. Lafaz yang digunakan Allah di dalam Al-Qur'an untuk menunjukkan perbuatan yang berakibat pada penelantaran, penistaan, atau merugikan orang lain ialah فحش dengan derivatderivatnya. Allah SWT menggunakan kata فش dan derivatnya di dalamAl-Qur'an sebanyak 24 kali, yaitu kata فحشاء sebanyak tujuh kali, lafaz فاحشة sebanyak 13 kali, dan lafazl فو احش sebanyak empat kali. Ini artinya bahwa perbuatan tersebut sangat dibenci oleh Allah SWT sehingga Allah SWT merasa perlu mengulanginya sampai 24 kali agar manusia memperhatikan larangan itu.

\section{Kehamilan}

Kehamilan merupakan hal yang paling ditunggu sekaligus mendatangkan rasa gelisah bagi pasangan suami dan istri. Setiap wanita akan mengharapkan kehamilan yang berjalan dengan lancar, sehat secara fisik, serta mengalami proses persalinan yang berjalan dengan lancar pula. Harapan ini membuat ibu hamil menikmati proses kehamilannya. Namun, rasa gelisah dan cemas hampir selalu menyertai kehamilan. Bagian ini merupakan suatu proses penyesuaian yang wajar terhadap perubahan fisik

${ }^{32}$ Ahmad Mustafa Al-Maragi, Tafsir Al-Maragi Jil. 18, p. 119.

${ }_{33}$ Muhammad Fuad Abdul Baqi, Al-Mu'jam al-Mufahras Li Alfadz al-Quran al-Karim (Jakarta: Angkasa), 540. 
dan psikologis yang terjadi selama kehamilan. Perubahan ini terjadi akibat perubahan hormon yang akan mempermudah janin untuk tumbuh dan berkembang sampai saat dilahirkan. ${ }^{34}$ Kecemasan yang dialami oleh ibu hamil dapat membuat seorang ibu hamil mengalami masalah, baik pada saat hamil maupun melahirkan, baik bagi kesehatan ibu maupun perkembangan bayi. Ketika seorang ibu hamil mengalami ketakutan, kecemasan, stres, dan emosi lain yang mendalam, maka terjadi perubahan psikologis, antara lain meningkatkan pernafasan, dan sekresi oleh kelenjar. ${ }^{35}$

Ayat-ayat Al-Qur'an yang menjelaskan tentang kehamilan sangat banyak, umumnya terkait dengan tanda-tanda adanya Allah, kebesaran dan kekuasaan Nya. Diantaranya, Al-Qur'an Surat Al-Mukminun/23 ayat 12-14:

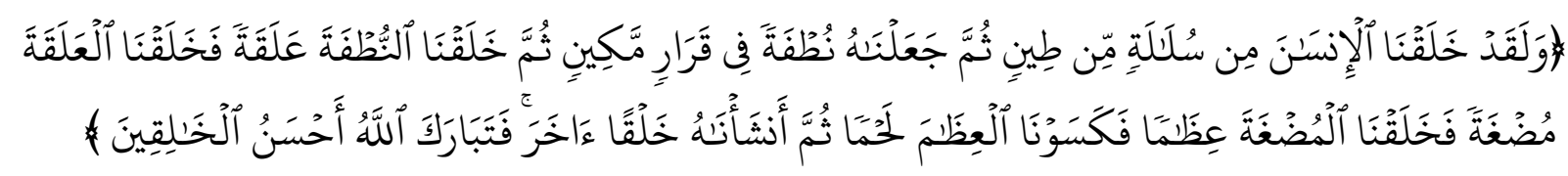

12. dan Sesungguhnya Kami telah menciptakan manusia dari suatu saripati (berasal) dari tanah. 13. kemudian Kami jadikan saripati itu air mani (yang disimpan) dalam tempat yang kokoh (rahim). 14. kemudian air mani itu Kami jadikan segumpal darah, lalu segumpal darah itu Kami jadikan segumpal daging, dan segumpal daging itu Kami jadikan tulang belulang, lalu tulang belulang itu Kami bungkus dengan daging. kemudian Kami jadikan Dia makhluk yang (berbentuk) lain. Maka Maha sucilah Allah, Pencipta yang paling baik. (QS Al-Mukminun/23: 12-14). ${ }^{36}$

Ayat tersebut mengisyaratkan adanya proses penciptaan manusia dalam alam arham (masa kehamilan), yang diawali dengan "sulalah min tin", kemudian "menjadi nutfah, 'alaqah, mudghah, 'izaman, lahman dan khalqan". Penciptaan manusia, berasal dari sulalah min tin, artinya saripati tanah, yaitu inti zat-zat yang ada dalam tubuh wanita dalam bentuk ovum dan dalam diri laki-laki dalam bentuk sperma. Sel telur yang telah dibuahi oleh sperma, atau zygote, disebut nutfah. Setelah terjadi pembuahan, zygote berjalan secara perlahan melalui tuba fallopi, menuju rahim. Setelah menempel di dinding rahim, berubah menjadi 'alaqah. Istilah 'alaqah, biasa diterjemahkan dengan segumpal darah. Penggunaan istilah 'alaqah oleh al-Qur'an sangat tepat, karena posisi zygote menggantung di dinding rahim. 'Alaqah juga berarti sesuatu yang menggantung.

34 Kushartanti, W., Soekamti, \& Sriwhayuniati, Senam Hamil: Menyamarkan Kehamilan, Mempermudah Persalinan (Yogyakarta: Lintang Pustaka: 2004, p. 8

35 Desmita, Psikologi perkembangan, Bandung: PT Remaja Rosdakarya, 2010, p. 76

36 Laznah Pentashihan Mushaf Al-Qur'an, Fenomena Kejiwaan Manusia dalam Perspektif Al-Qur'an dan Sains (Jakarta: Kementrian Agama RI, 2016), p. 6. 
Proses berikutnya, berubah menjadi mudghah, yang bentuknya seperti sekerat daging, kemudian tumbuh tulang ('izamaman) tulang dibungkas daging (lahman), selanjutnya menjadi khlaqan akhar (makhluk janin, yang sudah berbeda dengan kondisi awal terjadinya manusia). Kemudian Allah meniupkan ruh dalam janin.

“...Dia menjadikan kamu dalam perut ibumu kejadian demi kejadian dalam tiga kegelapan. QS Az-Zumar (39): $6 .{ }^{37}$

Ayat tersebut mengisyaratkan bahwa kehidupan janin dalam kandungan ibu sangat nyaman, karena ia berada dalam tiga kegelapan yaitu dilapisi tiga lapisan yang menyebabkan rahim ibu sangat nyaman untuk bayi. Al-Maraghi menafsirkan bahwa tiga kegelapan adalah perut, rahim dan selaput bayi. Sementara Dr. Abdul 'Aziz Isma'il menafsirkannya dengan tiga selaput yaitu selaput minbari, kharban dan lafaif.

\section{Persalinan}

Menurut ahli tafsir seluruh wanita untuk mempersiapkan diri dalam menghadapi proses kehamilan hingga persalinan. ${ }^{38}$ Ayat Al-Qur'an tentang persalinan, dimuat bersama-sama dengan ayat tentang kehamilan antara lain ada dalam QS. Al-Ahqaf/46:15.

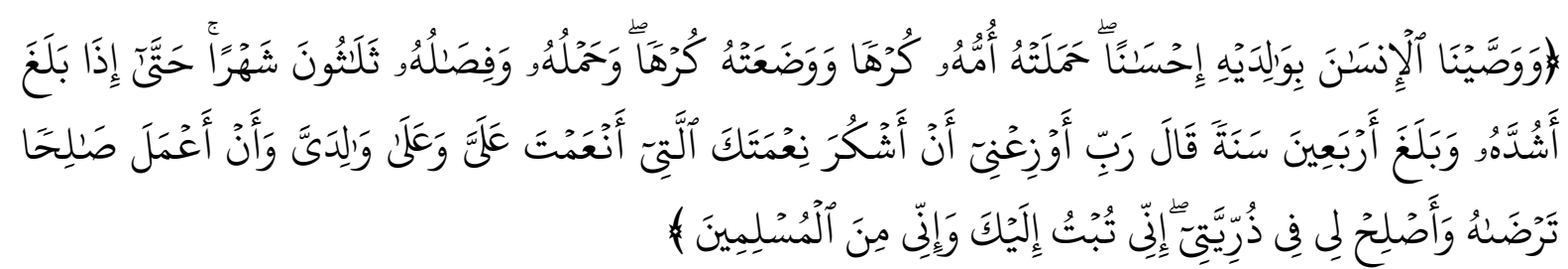

"Kami perintahkan kepada manusia supaya berbuat baik kepada dua orang ibu bapaknya, ibunya mengandungnya dengan susah payah, dan melahirkannya dengan susah payah (pula) mengandungnya sampai menyapihnya adalah tiga puluh bulan..."39

Ayat tersebut menjelaskan bahwa salah satu alasan kenapa Allah memberi wasiat pada manusia agar berbakti pada kedua orang tua adalah karena proses persalinan yang dialami ibu merupakan suatu proses yang sangat berat. Pengaruh kontraksi rahim ketika bayi mau lahir, menyebabkan ibu merasakan sangat kesakitan, bahkan dalam keadaan tertentu, dapat menyebabkan kematian. Karena perjuangan ibu ketika melahirkan dan resiko yang sangat berat yang ditanggung seorang ibu, Nabi cukup bijaksana dan

\footnotetext{
${ }^{37}$ Departemen Agama RI, Mushaf Al-Qur'an Terjemah (Jakarta: Pena Pundi Aksara, 2002), p. 460.

${ }^{38}$ Suryani, Intan. "Studi Literatur: Konsep Pembentukan Janin Dalam Perspektif Al-Quran Dan Sains." Jurnal Penelitian Pendidikan Guru Sekolah Dasar 7.1 (2019).

39 Ahmad Mustafa Al-Maragi, Tafsir Al-Maragi Jil. 26, Terjemahan Anshori, Hery, Bahrun (Semarang: Toha Putra, 1992), p. 24-5.
} 
memberi empati pada ibu yang meninggal karena melahirkan sebagai syahid, setara dengan perjuangan jihad di medan perang.

Penghargaan itu diberikan Nabi sebagai rasa empati karena musibah yang dialami dan juga beratnya resiko kehamilan dan melahirkan bagi seorang ibu. Hal ini bukan berarti membiarkan ibu yang akan melahirkan agar mati syahid, tetapi justru memberi isyarat agar dilakukan upaya-upaya perlindungan, pemeliharaan kesehatan dan pengobatan pada ibu pada masa-masa kehamilan dan melahirkan. Namun bila ibu meninggal karena melahirkan, Allah menilainya sebagai perjuangan dan meninggal dalam keadaan syahid. Sabda Nabi Muhammad SAW., yang artinya:

"Ada tujuh mati syahid selain mati dalam peperangan membela agama: orang yang mati karena terserang wabah tha'un (kolera), orang yang mati karena tenggelam, orang yang mati karena sakit pinggang, orang yang mati karena sakit perut, orang yang mati terbakar, orang yang mati karena tertimpa reruntuhan dan wanita yang mati karena kehamilan dan persalinan".(HR. Abu Dawud). ${ }^{40}$

\section{Menyusui}

Islam memuliakan perempuan antara lain dengan kekhususannya memiliki fungsi reproduksi, yang digambarkan sebagai perjuangan yang sangat berat, dan oleh Al-Qur'an dijadikan alasan megapa anak diberi wasiat supaya berbuat ihsan pada kedua orang tuanya. pada saat ibu menyusui anaknya, sebenarnya ia sedang mencurahkan kasih sayangnya kepada anaknya Apalagi ketika dalam posisi menyusui, ibu sambil mendengungkan, melantunkan shalawat. ${ }^{41}$ Sehingga detak jantung ibu yang didengar bayi saat menyusu akan mempengaruhi fungsi kognitif anak. ${ }^{42}$ Menurut WHO, setiap ibu dianjurkan untuk menyusui anaknya secara eksklusif selama 6 bulan, lalu boleh dilanjutkan hingga satu tahun, dua tahun, atau kapanpun si ibu dan anak menginginkannya. ${ }^{43}$

\footnotetext{
${ }^{40}$ Abu Dawud, Dalam Kitab Sunan Abu Daud, Juz 8, Nomor Hadits 2704 (Maktabah Syamilah), p. 366.

41 Taubah, Mufatihatut. "Pendidikan Anak Dalam Keluarga Perspektif Islam." Jurnal Pendidikan Agama Islam (Journal of Islamic Education Studies) 3.1 (2015), p. 109-136.

42 Wahyuningtyas, Dessy Putri, and Rikza Azharona Susanti. "Tingkat Pemberian ASI dalam Orientasi Islam terhadap Kognitif Anak Usia 4-6 Tahun di Kota Malang." Jurnal Warna 3.1 (2019), p. 6075.

43 Rahmawati, Rina Dian, and Diki Cahyo Ramadhan. "Manfaat Air Susu Ibu (ASI) Pada Anak Dalam Persepektif Islam." eduscope 5.01 (2019), p. 24-34.
} 
Menyusui juga merupakan salah satu fungsi reproduksi. Ayat yang menjelaskan tentang menyusui antara lain Surat Al-Baqarah/2:233, Luqman/31:14 dan AlAhqaf/36:15. "Para ibu hendaklah menyusukan anak-anaknya selama dua tahun penuh, Yaitu bagi yang ingin menyempurnakan penyusuan."

Dengan menggunakan redaksi ayat di atas memerintahkan dengan sangat kokoh kepada para ibu agar menyusukan anak-anaknya. ${ }^{44}$ Mayoritas ulama berpendapat bahwa ibu wajib menyusui bayinya dengan dasar bunyi wa al-wâlidât yurdi'n awlâdahunn. Potongan ayat tersebut merupakan perintah. Menurut mazhab Mâlikî, aktivitas menyusui merupakan kewajiban ibu dalam kehidupan rumah tangga. Itu merupakan kewajibannya jika si ibu berstastus sebagai seorang istri atau jika si bayi menolak puting selain puting susu ibunya. ${ }^{45}$ Tetapi berdasarkan bunyi kalimat selanjutnya li man arâda an yutimm alradâ'ah (bagi yang ingin menyempurnakan penyusuan), maka ayat ini bisa dipahami sebagai suatu anjuran bagi ibu untuk menyusui selama dua tahun penuh. Namun demikian, ia adalah anjuran yang sangat ditekankan, seakan-akan ia adalah perintah wajib.

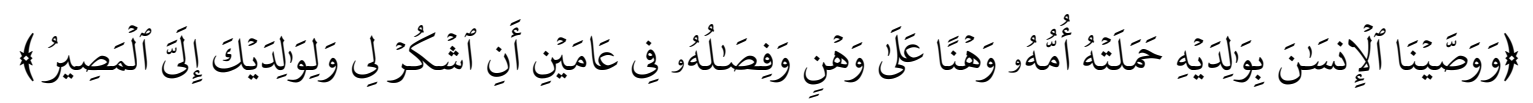

"Dan Kami perintahkan kepada manusia (berbuat baik) kepada dua orang ibubapanya; ibunya telah mengandungnya dalam Keadaan lemah yang bertambahtambah, dan menyapihnya dalam dua tahun. Bersyukurlah kepadaku dan kepada dua orang ibu bapakmu, hanya kepada-Kulah kembalimu. (QS Luqman (31):14).46

Lihat juga ayat "Kami perintahkan kepada manusia supaya berbuat baik kepada dua orang ibu bapaknya, ibunya mengandungnya dengan susah payah, dan melahirkannya dengan susah payah (pula) mengandungnya sampai menyapihnya adalah tiga puluh bulan." 47

Ketiga ayat tersebut menjelaskan tentang hal-hal yang terkait dengan perempuan menyusui:

${ }^{44}$ M. Quraish Shihab, Tafsir Al-Mishbah, Pesan Kesan dan Keserasian Al-Qur'an, Jakarta: Lentera Hati, 2000, Jilid I, p. 609.

45 Muhammad „Alî al-Sâbûnî, Rawâi' al-Bayân: Tafsîr Ayât al-Ahkâm, Vol. 1 (Beirut: Maktabah alGhazâlî, 1980), p. 68.

${ }^{46}$ Departemen Agama RI, Mushaf Al-Qur'an Terjemah (Jakarta: Pena Pundi Aksara, 2002), p.413.

47 Ahmad Mustafa Al-Maragi, Tafsir Al-Maragi Jil. 26, Terjemahan Anshori, Hery, Bahrun (Semarang: Toha Putra, 1992), p. 24-25. 
- Bahwa ibu hendaknya memberikan asi pada bayi yang dilahirkannya. Asi merupakan nutrisi alamiyah yang disediakan Allah untuk menunjang kehidupan bayi.

- Masa menyusui diisyaratkan oleh al-Qur-an ada dua pilihan. Pertama 2 tahun penuh, bila mau memberikan asi secara sempurna. Kedua 21 bulan, yang difahami dari QS. Al-Ahqaf, bahwa masa kehamilan sampai menyapihnya adalah 30 bulan. Bila masa kehamilan 9 bulan, maka masa menyusui 21 bulan.

- Hak reproduksi perempuan menyusui yang harus dipenuhi suami adalah mendapatkan pemenuhan kebutuhan hidupnya yaitu kebutuhan makanan, pakaian (termasuk perawatan kesehatan).

- Hak mendapatkan perlindungan dan perlakuan yang baik.

- Bila karena sesuatu hal, ibu tidak dapat menunaikan fungsi reproduksi menyusui, atas dasar musyawarah keluarga, mencari perempuan lain untuk menyusui bayinya dengan memberi imbalan jasa.

\section{Perawatan Anak}

Mendidik anak dengan cara-cara yang baik dan sabar agar mereka mengenal dan mencintai Allah, yang menciptakannya dan seluruh alam semesta, mengenal dan mencintai Rasulullah shallallaahu 'alaihi wa sallam, yang pada diri beliau terdapat suri tauladan yang mulia, serta agar mereka mengenal dan memahami Islam untuk diamalkan. Ajarkanlah Tauhid, yaitu bagaimana mentauhidkan Allah, dan jauhkan serta laranglah anak dari berbuat syirik. Sebagaimana Allah SWT berfirman dalam al- Qur'an terkait dengan pemeliharaan anak. Sebagaimanan nasihat Luqman kepada anaknya,

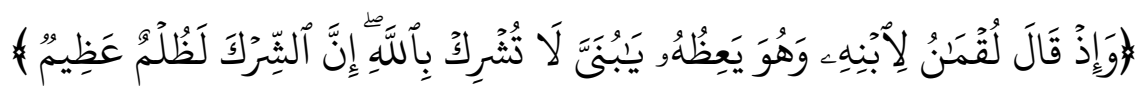

"Dan (ingatlah) ketika Luqman berkata kepada anaknya, ketika ia memberi pelajaran kepadanya, 'Wahai anakku! Janganlah engkau memperskutukan Allah, sesungguhnya mempersekutukan (Allah) adalah benar-benar kezhaliman yang besar." [Luqman: 13]

Dalam tumbuh dan berkembang anak di bawah asuhan dan perawatan orang tuanya dalam bentuk pengasuhan anak tidak hanya terbatas merawat atau mengawasi 
anak saja, melainkan ${ }^{48}$ mendidik, merawat, memberikan kasih sayang kepadanya. ${ }^{49} \mathrm{Di}$ masyarakat kita adalah fenomena kesibukan ibu dari peran utamanya sehingga merawat anak dibebankan ke orang lain maka akan kehilangan kasih sayang, sebab sang ibu membiarkannya dalam perawatan anak kepada orang lain. Dan Sebaliknya, ada anak yang menjadi orang shaleh sekalipun terdidik di tengah-tengah orangtuanya bahkan bukan orangtuanya sendiri. ${ }^{50}$ Dalam tugas urusan rumah tangga termasuk merawat anak adalah kewajibannya orang tuanya ibunya sementara ayah harus mengambil alih tugastugas perawatan yang lain. ${ }^{51}$ Sehingga orangtua memiliki tanggung jawab kepada anak dalam berbagai hal, baik pemeliharaan, dan menjaga perawatan kesehatan anak..$^{52}$

Mengasuh dan merawat anak merupakan pekerjaan yang mulia, yang umumnya menjadi tanggung jawab penuh seorang istri, dan seakan menjadi kodrat yang harus diembannya, keberhasilan seorang istri sekaligus ibu menjalani proses reproduksi sejak kehamilan yang sehat hingga lahir anak yang sehat fisik dan mental, bukan hanya tanggung jawab istri. Janin yang tumbuh dalam rahim istri merupakan benih berdua, merupakan buah kasih sayang antara suami dan istri dalam ikatan perkawinan yang suci.

Oleh karena itu, suami perlu melibatkan diri selama istri menjalani kehamilan, persalinan dan juga saat istri mulai mengasuh dan merawat bayinya. Keterlibatan suami lebih banyak bersifat dukungan psikis sehingga istri merasa tenang dan tentram karena merasa diperhatikan oleh pasangan yang dicintainya. Umumnya, masyarakat kita telah menerapkan atau menentukan bahwa mengasuh serta merawat anak lebih tepat dilakukan oleh kaum perempuan. Hal ini dilatarbelakangi oleh budaya masyarakat yang berlaku dalam keluarga bahwa perempuan bertemperamen "feminim" dan memiliki kecendrungan mengasuh anak. Hal ini berimplikasi dan memperkuat ketetapan buat lakilaki seolah-olah mangasuh anak merupakan jawab azali perempuan. ${ }^{53}$

48 Zaki, Muhammad. "Perlindungan Anak dalam Perspektif Islam." ASAS, 6.2 (2014).

${ }^{49}$ Faradz, Haedah. "Pengangkatan Anak Menurut Hukum Islam." Jurnal Dinamika Hukum, vol. 9, no. 2 (2009), p. 191-98.

${ }^{50}$ Lahir, Memperhatikan Anak Sebelum. "Pendidikan anak dalam Islam." (1999).

51 Zidni, Ervi Siti Zahroh. "Kemitraan Keluarga dalam Menangkal Radikalisme." Jurnal Studi AlQur'an, vol. 14, no. 1 (2018), p. 32-43.

52 Fajarwati, Indah. "Konsep Montessori tentang pendidikan anak usia dini dalam perspektif pendidikan Islam." Jurnal Pendidikan Agama Islam UIN Sunan Kalijaga, vol. 11, no. 1 (2014), p. 37-52.

53 Amina Wadud, Al-Qur'an Menurut Perempuan (Jakarta: Serambi Ilmu Semeta, 2006), p. 156 
Dengan demikian, tumbuh kecenderungan yang kuat untuk menyerahkan semua bentuk pengasuhan dan perawatan anak kepada kaum perempuan (istri). Meskipun pembagian kerja ini cocok bagi beberapa keluarga, terutama jika suami mencari nafkah, tetapi itu bukan satu-satunya jalan dan al-Qur'an pun tidak mengaturkan hal ini secara tegas. Al-Qur'an memberikan hak kepada bapak maupun ibunya berkenan dengan anakanak ini dan menghargai keteriakan emosional mereka. Hal ini ditegaskan oleh Allah dalam penggalan ayat Al-Baqarah ayat 233 yang berbunyi: Janganlah seorang ibu menderita kesengsaraan karena anaknya dan seorang ayah karena anaknya.

Dalam keluarga yang nafkah materinya disangga oleh suami dan istri, maka tidak adil jika semua beban pekerjaan rumah tangga dipikul sendiri oleh istri. Jika perempuan telah berusaha meambah amal baiknya, maka ada kesempatan yang sama bagi laki-laki untuk menambah amal baikya, maka ada kesempatan yang sama bagi laki-laki untuk menambah amal baiknya dengan lebih banyak berpartisipasi dalam pekerjaan rumah tangga dan perawatan anak. Secara ekplisit, al-Qur'an mendeskripsikan dalam surat anNisa' ayat 124 tentang sistem evaluasi tertingginya dalam menghargai semua perbuatan, baik itu dilakukan laki-laki maupun perempuan. 54

Sistem kerja sama yang fleksibel, terpadu dan dinamis seperti itu menguntungkan bagi beragam masyarakat dan tipe keluarga. Hal ini tidak terlepas dari pemaknaan kita secara utuh terhadap al-Qur'an, tidak secara parsial. Dengan demikian, perhatian terhadap perempuan dalam masyarakat dan potensi yang dimilikinya pasti lebih besar dari sekedar merendahkan dan meremehkan eksistensi perempuan yang dicap hanya berfungsi sebagai pelayan rumah tangga. Untuk itu pula, keahlian dan partisipasi perempuan di rumah juga akan dianggap penting dan bermakna, sehingga siapapun ingin mengerjakan amal baik dan bergerak untuk melaksanakan tugas-tugas dalam rumah tangga. 55

Hal ini merupakan tujuan dari apa yang dicita-citakan oleh masyarakat Islam dan sejalan dengan tujuan al-Qur'an yang berkenan dengan hak, tanggung jawab, potensi, dan kapasitas dari semua anggota masyarakat dalam sebuah keluarga, yaitu berharap agar perempuan mendapat kesempatan untuk berkembang dan produktif sebagaimana yang

54 Sayyid Qutub, Tafsir fi Zhilal al-Qur'an, Jakarta: Gema Insani Press, 2001, p. 202

55 Amina Wadud, Al-Qur'an Menurut Perempuan, p. 155 
diharapkan dari laki-laki, yaitu akan turut bertanggung jawab untuk mengasuh anak dan merawat anak dan keluarga di samping mengurusi masalah materi dan akhirnya keduanya akan saling melengkapi dan menguntungkan bagi satu sama lain, bagi keluarga dan untuk masyarakat luar nantinya.

\section{G. Kesimpulan}

Dalam penelitian ini dapat disimpulkan bahwa: Konsep kesehatan reproduksi perempuan menurut al-Qur'ān terdiri dari enam konsep, yaitu: Menstruasi (Haid), Seks dan Seksualitas, kehamilan, persalinan, menyusui, dan perawatan anak. Dari sisi biologis, perempuan yang sudah mengalami haid merupakan indikasi bahwa perempuan tersebut telah mampu bereproduksi, yakni mengalami proses kehamilan dan melahirkan. AlQur'an menyinggung maslah haid, yang merupakan bagian awal dari proses bimbingan dan perhatian terhadapan kesehatan reproduksi perempuan. Haid adalah keluarnya darah kotor dari rahim perempuan.

Oleh sebab itu janganlah dekati, yaitu bersetubuh dengan istri di waktu haid. Karena darah haid itu darah yang kotor dan dapat meyebabkan berbagai penyakit, diantaranya adalah bagi laki-laki akan terkena kencing nanah, sifilis, dan bagi perempuan mengakibatkan rusaknya pada indung telur dan bisa menyebabkan kemandulan. Sedangkan Seks adalah perbedaan badani atau biologis perempuan dan laki-laki, yang sering disebut jenis kelamin. Sedangkan seksualitas menyangkut berbagai dimensi yang sangat luas, yaitu dimensi biologis, sosial, psikologis dan kultural.

Kehamilan dan melahirkan bagi seorang ibu merupakan proses yang sangat sulit, karena untuk menjalaninya pasti ada suatu problem disaat masa kehamilan dan proses melahirkan, seperti yang terdapat dalam surat al-Ahqof: 15, bahwa sang ibu mengandungnya dengansusah payah, sambil mengalami aneka kesulitan bermula dari mengidam, dengan aneka gangguan fisik dan psikis, dan melahirkannya dengan susah payah setelah berlalu masa kehamilan.

Sedangkan menyusui merupakan kewajiban bagi seorang ibu kepada anaknya, karena ASI tersebut sangat berguna bagi bayi, terutama di awal usianya yang sangat membutuhkan makanan, dan makanan itu adalah ASI. ASI tersebut memiliki banyak manfaat bagi ibu dan anaknya, diantaranya adalah ikatan batin antara ibu dan anak, dapat 
memberikan antibodi sistem kekebalan bagi bayi, dan dapat menghidarkan ibu dari kanker payudara dan kanker rahim, juga bisa menurunkan berat badan yang berlebihan bagi ibu.

Dan merawat anak dalam tugas urusan rumah tangga termasuk merawat anak adalah kewajibannya orangtuanya, sehingga orangtua memiliki tanggung jawab kepada anak dalam berbagai hal, baik pemeliharaan, dan menjaga perawatan kesehatan anak. Karena mengasuh dan merawat anak merupakan pekerjaan yang mulia bagi orangtuanya. 


\section{Daftar Pustaka}

Abu Dawud, Dalam Kitab داود أبي سنن Bab الطاعون في مات من فصل في , Juz 8, Nomor Hadits 2704, Maktabah Syamilah.

Al-Maragi, Ahmad Mustafa, Tafsir Al-Maragi Jil. 2, Terjemahan Anshori, Hery, Bahrun, Semarang: Toha Putra, 1992.

----, Tafsir Al-Maragi Jil. 15, Terjemahan Anshori, Hery, Bahrun Semarang: Toha Putra, 1993.

----, Tafsir Al-Maragi Jil. 18, Terjemahan Anshori, Hery, Bahrun Semarang: Toha Putra, 1992.

----, Tafsir Al-Maragi Jil. 26, Terjemahan Anshori, Hery, Bahrun Semarang: Toha Putra, 1992.

Al Fanjari, Ahmad Syauqi, Nilai Kesehatan Dalam Syariat Islam, Terjemahan, Diterjemahkan Oleh Ahsin Wijaya Totok Jumantoro, Jakarta: Bumi Aksara, 1996.

Al-Baihaqi, Dalam Kitab للبيهقس الايمان شعب, Juz 8,Nomor Hadits 9882, Maktabah Syamilah

Al-Jauziyah, Al-Imam Ibnu Qayyim, Jangan Dekati Zina, Terjemahan Tim Darul Haq, Jakarta: Darul Haq, 2012

Ahnan, Mahtuf, Maria Ulfa, Risalah Fiqih Wanita, Surabaya: Terbit Terang, tt.

Al-Barudi, Syaikh Imad Zaki, Tafsir Wanita, Terjemahan, Terjemahan Samson Rahman, Jakarta: Pustaka Al-Kautsar, 2010.

Al-Jamal, Ibrohim Muhammad, Fiqhul Mar'atil, Terj, Jakarta: Pustaka Amani, 1994.

Al-Sâbûnî, Muhammad Alî, Rawâi' al-Bayân: Tafsîr Ayât al-Ahkâm, Vol. 1 Beirut: Maktabah al-Ghazâlî, 1980.

Ambaretnani, Prihatini, dkk, Upaya Meningkatkan dan Melindungi Kesehatan Reproduksi TKWI, Yogyakarta: Galang Press, 1996.

As-Shabuni, Syekh Muhammad Ali, Ikhtisar Ulumul Qur'an Praktis, Jakarta: Pustaka Amani, 2001.

Baqi, Muhammad Fuad Abdul, Al-Mu'jam al-Mufahras Li Alfadz al-Quran al-Karim, Jakarta: Angkasa, tt.

Departemen Agama RI, Mushaf Al-Qur'an Terjemah, Jakarta: Pena Pundi Aksara, 2002.

----, Mushaf Al-Qur'an Terjemah, Jakarta: Pena Pundi Aksara, 2002.

Departemen Pendidikan Nasional, Kamus besar Bahasa Indonesia Pusat Bahasa Edisi Keempat, Jakarta: Gramedia, 2008.

Derek Llewellyn, Jones, Ginekologi \& Kesehatan Wanita, Terjemahan Kartono Muhammad, Jakarta: Gaya Favorit Press, 1991.

Desmita, Psikologi perkembangan, Bandung: PT Remaja Rosdakarya, 2010.

Fajarwati, Indah. "Konsep Montessori tentang pendidikan anak usia dini dalam perspektif pendidikan Islam." Jurnal Pendidikan Agama Islam UIN Sunan Kalijaga, vol. 11, no. 1 (2014).

Faradz, Haedah. "Pengangkatan Anak Menurut Hukum Islam." Jurnal Dinamika Hukum, vol. 9, no. 2 (2009), pp. 191-198. 
French, Kathy, Kesehatan Seksual, Terjemahan, Terjemahan Bhetsy Angelina, Jakarta: Bumi Medika, 2015.

Hassan Hathout, Bimbingan Seks Lengkap Bagi Kaum Muslim, Terjemahan, Terjemahan Yudi, Jakarta: Zahra, 2014.

Intan Kumala Sari, Iwan Andhyantoro, Kesehatan Reproduksi Untuk Mahasiswa Kebidanan dan Keperawatan Jakarta: Salemba Medika, 2012.

Kesuma, Arsyad Sobby, Diskursus Tafsir Hak-hak Politik Perempuan Dalam Al-Qur'an, Studi Tafsir Al-Misbah, IAIN Raden Intan Lampung: LP2M, 2016.

Kushartanti, W., Soekamti, \& Sriwhayuniati, Senam hamil: menyamarkan kehamilan, mempermudah persalinan, Yogyakarta: Lintang Pustaka: 2004.

Kusmiran, Eny, Kesehatan Reproduksi Remaja dan Wanita, Jakarta: Salemba Medika, 2012.

Lahir, Memperhatikan Anak Sebelum. "Pendidikan anak dalam Islam." (1999).

Laznah Pentashihan Mushaf Al-Qur'an, Fenomena Kejiwaan Manusia Dalam Perspektif AlQur'an dan Sains, Jakarta: Kementrian Agama RI, 2016.

Qutub, Sayyid, Tafsir fi Zhilal al-Qur'an, Jakarta: Gema Insani Press, 2001.

Rahmawati, Rina Dian, and Diki Cahyo Ramadhan. "Manfaat Air SSusu Ibu (ASI) Pada Anak Dalam Persepektif Islam." Eduscope, vol. 5, no. 1 (2019): 24-34.

Ramadhy, Asep Sufyan, Biologi Reproduksi,(Bandung: Refika Aditama, 2011.

Shihab, M. Quraish, Tafsir Al-Mishbah, Pesan Kesan dan Keserasian Al-Qur'an, Jilid I Jakarta: Lentera Hati, 2000.

Suryani, Intan. "Studi Literatur: Konsep Pembentukan Janin Dalam Perspektif Al-Quran Dan Sains." Jurnal Penelitian Pendidikan Guru Sekolah Dasar, vol. 7, no. 1 (2019).

Taubah, Mufatihatut. "Pendidikan Anak Dalam Keluarga Perspektif Islam." Jurnal Pendidikan Agama Islam (Journal of Islamic Education Studies, vol. 3, no. 1 (2015).

Wadud, Amina, Al-Qur'an Menurut Perempuan, Terj, Jakarta: Serambi Ilmu Semeta, 2006.

Wahyuningtyas, Dessy Putri, and Rikza Azharona Susanti. "Tingkat Pemberian ASI dalam Orientasi Islam terhadap Kognitif Anak Usia 4-6 Tahun di Kota Malang." Jurnal Warna, vol 3, no. 1 (2019).

Zaki, Muhammad. "Perlindungan Anak dalam Perspektif Islam." ASAS, vol. 6, no. 2 (2014).

Zidni, Ervi Siti Zahroh. "Kemitraan Keluarga dalam Menangkal Radikalisme." Jurnal Studi Al-Qur'an, vol. 14, no. 1 (2018). 